the level of the lake in the afternoon, I obtained readings of the level at Entebbe by the official recorder at 8 A.M., noon, and 4 P.M. On three successive days the records were as follows :

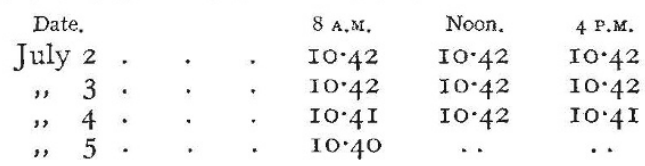

This explanation, therefore, is not possible, and indeed seems improbable in consideration of the vast size of the lake and the relatively small amount of water poured into it by the Kagera and smaller rivers, of which the Yala is one. The inflow would need to be very much larger in order to raise the level of the whole lake during a single night.

G. D. HALE CARPEnTER, Uganda Medical Service.

Entebbe, Uganda, July 5.

\title{
English Enemies of the American Slipper-limpet, Crepidula fornicata.
}

IN 1923 the present writer found a shell of a dead slipper-limpet (Crepidula fornicata) at West Mersea, Essex, bored extensively by the boring sponge Cliona celata. This year a good number of living slipperlimpets have been examined, and one, the fourth individual of a chain of 8 living ones, was found with the living sponge boring into the shell. In the shell of the dead animal the sponge could be seen to have bored through all parts including the shelf, but had been inhibited from perforating over almost the whole of the area on the dorsal side, where another slipperlimpet had been attached to it. In the living specimen the sponge can be seen to be forming a honeycomb mesh-work in the dorsal portion of the shell, but it has only perforated to the surface in the postero-dorsal region; the shelf of the shell is also attacked and is almost perforated in places. On the part of the shell where the next individual in the chain was sitting there is a nodular deposition of calcareous matter over strands of the sponge tissue. This deposit has been laid down, not by the owner of the shell, but by the individual sitting on the shell, and undoubtedly as a reaction to the irritation caused by the sponge. Crepidula has, therefore, found an enemy in Cliona in its new environment, and it will be interesting to know to what extent the slipperlimpet will be attacked in future in view of its economic importance.

Crepidula has other enemies. I have observed the whelk-tingle, Ocinebra (Murex) erinacea, attack the shell of Crepidula and bore through to the body, and shells can be found on the oyster-beds also bored either by Murex or Purpura, but it is difficult to estimate whether the boring whelks are of much value in killing off numbers of Crepidula. Whitstable fishermen know that dabs, Pleuronectes limanda, eat Crepidula, and I have seen fresh slipper-limpets in recently opened stomachs of this fish, but it seems likely that many of these limpets are obtained from chains broken in the dredging operations. Mr. Luckhurst, of Whitstable, informs me that starfishes, Asterias rubens chiefly, attack Crepidula, especially in winter time, when the slipper-limpets have apparently been weak. Since Crepidula was introduced into England from America round about the year 1880 , it will be interesting to know from time to time in the future what English marine animals become inimical to it. At present Crepidula appears to be maintaining its dominance in the rich waters of the Thames Estuary; this year there is a great fall

of spat in many places in the north-western portion of the Estuary, although for the last few years the spatfall has been below the average in most places.

$$
\begin{gathered}
\text { Marine Biological Laboratory, } \\
\text { Plymouth, July } 29 .
\end{gathered}
$$

J. H. ORTON.

\section{Former Fertility of the Kalahari Desert.}

Prof. J. W. Gregory, in his article on my recent Kalahari pamphlet in NATURE of April I2, p. 539 , objected to my citing the Sylphium of Cyrenaica as evidence of the former fertility of the desert. I also gave the wine palm, Raphia monbuttorum, as evidence; for, whereas it formerly lived in the Egyptian oases, it is now confined to the more humid regions further south. Hassanein Bey has recently given evidence to the same effect in the oases of Kufra and Ouenat. In the latter place he describes rock drawings of ostriches, giraffes, and other animals that require grassland, and could not possibly live in the desert as it is to-day. The fact that there are no camels shown indicates that the pictures were made before A.D. 640 , when the Arabs arrived in Africa with their camels. Nowadays, life in Ouenat would be impossible without these animals.

In South Africa we have the same evidenceBushman drawings of hippopotamus, rhinoceros, and other animals, where these could not live to-day, although we know they lived all about here Ioo-r 50 years ago. The last lion, hippopotamus, and rhinoceros were shot in the neighbourhood by the fathers of people still living in Grahamstown. I have already given the evidence of the Yellow-wood (Podocarpus), the typical Knysna forest tree, still lingering on hills in Namaqualand in what is now practically desert, and a few specimens are found on isolated hills between there and Cape Town. Recently, however, I have been shown by my neighbour, Mr. M. G. Godlonton, a specimen of the Winterberg bamboo (Arundinaria tessellata, Monroe), growing in his garden, which is a striking proof of more humid conditions not very long ago. It was only one hundred and fifty years ago since Barrow, Lichtenstein, and le Vaillant saw our Karroo plains swarming with big game, as now in Uganda, and we have every reason to believe that at that time the slopes of the mountains were covered with bamboo forest as now on the Nandi plateau in Central Africa, and of which these few stray stragglers still survive.

The Winterberg is about $7000 \mathrm{ft}$. and some 50 miles north of Grahamstown. E. H. L. ScHwarz.

Rhodes University College,

Grahamstown, July i6.

\section{Chalky Boulder Marl at Hastings.}

As relief workers in the Hastings district are continuously laying bare geological sections of first-class importance, and as the demands upon my time have precluded the possibility of my bringing the full details before scientific societies, I feel that geologists in general would be interested in a short account of them in the pages of NATURE. They relate not only to Wealden but also to Pliocene and Pleistocene times.

WEALDEN.-Excavations in the Wadhurst clay have brought to light a remarkable richness of both vegetable and animal life, particularly among the mollusca, in which Nature has shown herself most energetic, not only in the cases of well-known genera and species of ordinary character-necessitating a revision of the Wealden mollusca-but in others she has shown great prodigality, some of the gastropods-dextral and sinistral-attaining a length, or height, of sixty feet

No. 286 I, VOL. I I 4 ] 